\title{
PENGARUH PENILAIAN KINERJA TERHADAP MOTIVASI DAN PRODUKTIVITAS KERJA KARYAWAN PADA HOTEL PANGRANGO 2 BOGOR
}

\author{
Janusi Waliamin \\ Universitas Prof. DR Hazairin, SH \\ jwaliamin@gmail.com
}

\begin{abstract}
Abstrak
The hotel business in the city of Bogor has increased from year to year which has increased business competition. Then it is followed by a performance appraisal of employees whose aim is to monitor and maintain the performance of the selected employees because the performance appraisal will affect the follow-up needed by the employees relating to staffing decisions, for example promotion, payroll, or development. Based on this, this study aims to analyze the effect of performance appraisal on employee motivation and work productivity at the hotel pangrango 2 in Bogor.This type of research used in this study was a quantitative approach or statistical data analysis. The data sources were obtained from distributing questionnaires to 133 employees. The validity of the data was analyzed using the Product Moment Pearson correlation technique formula while the reliability of the measuring instrument was carried out using the Alfa Cronbach technique. The results showed that the employees of the Hotel Pangrango 2 Bogor used self-appraisal techniques, the effect of evaluation on motivation had a positive effect, the place of evaluation had no effect on employee motivation, the evaluation method on motivation had a negative effect, and motivation had a positive effect on the employees' work productivity. Based on the results of the analysis of the research, the Hotel Pangrango 2 Bogor really needs to pay attention to performance evaluation factors because it is very influential on employee motivation and motivation itself will affect employees' performance productivity.
\end{abstract}

Keywords: Performance appraisal, motivation, work productivity, hotel

\section{PENDAHULUAN}

Menurut data dari dinas informasi pariwisata dan kebudayaan (Disparbud) pemerintah kota Bogor tahun 2016, bisnis perhotelan di Kota Bogor terus mengalami kenaikan yang signifikan baik dari jumlah usaha hotel, jumlah kamar hotel dan jumlah tempat tidur dalam hotel (tidak membedakan tipe kamar). Selain itu, kunjungan wisatawanpun dari wisatawan lokal hingga manca negara ke kota Bogorjuga mengalami kenaikan dari tahun ke tahun. Letak geografis kota Bogor yang sangat strategisyang merupakan kota lintasan utama dan pintu gerbangnya Jawa Barat menjadikan Bogor sebagai kota satelit dari ibu kota Jakarta sehingga membuat bisnis perhotelan semakin berkembang. Begitu juga dengan hotel pangrango 2 Bogor yang mengalami kenaikan baik dari jumlah kamar maupun jumlah tempat tidur.Seiring dengan peningkatan tersebut, pihak manajemen hotel selain harus meningkatkan kualitas sarana dan prasarana hotel, kualitas sumber daya manusianya juga perlu ditingkatkan.Untuk itu, karyawan hotel harus memahami pentingnya memberi kepuasan kepada para tamu dan dapat melihat segala hal dari sudut pandang para tamu dan mempertahankan kepuasan para tamu untuk kembali menggunakan jasa hotel. Kualitas sumberdaya manusia atau karyawan hotel memegang perananyang tidak dapat dihindari lagi untuk kelangsungan hidup usaha perhotelan. Menurut Olsen dan Wyckoof (2006), dalam industri perhotelan sebagian besar produk ditawarkan berupa produk pelayanan atau jasa. Para praktisi sumber daya manusia menilai bahwa penilaian kinerja karyawan adalah suatu unsur penting dalam sistem sumberdaya 
manusia itu sendiri. Dimulai dengan seleksi yang disebut sebagai memilih orang yang tepat untuk suatu pekerjaan yang tersedia. Penilaian kinerja terhadap karyawan yang bertujuan memonitor dan mempertahankan kinerja karyawan yang terpilih pada suatu tingkatan tertentu, sehinggah penilaian kinerja akan berpengaruh terhadap tindak lanjut yang diperlukan karyawan yang berkaitan dengan keputusan kepegawaian, misalnya promosi, demosi, penggajian, atau langkah-langkah pengembangan. Karena itu, sangat diperlukan suatu penilaian kinerja yang mampu memenuhi fungsi-fungsinya secara utuh dalam kaitannya dengan peningkatan kualitas sumber daya manusia. Sistem penilaian kinerja diperusahaan atau organisasi merupakan bagian yang tidak terpisahkan dari suatu sistem manajemen kinerja yang memiliki tujuan khusus untuk membantu pengembangan karyawan, sebagai penjabaran visi dan misi perusahaan atau organisasi. Proses penilaian kinerja memegang peranan yang cukup penting baik bagi karyawan yang dinilai maupun penilai. Kurang jelasnya kriteria penilaian sering kali dikeluhkan karyawan baik yang berada dalam satu divisi maupun yang berbeda divisi. Kecenderungan pemberian nilai yang selalu tinggi atau yang selalu rata-rata menjadi halangan bagi optimalisasi pelaksanaan penilaian kinerja. Karyawan juga sering kali merasa adanya kekurangan dalam pengamatan atasan terhadap kinerja bawahan secara menyeluruh dari waktu ke waktu. Prosess penilaian kinerja secara formal yang dilakukan setahun sekali, dianggap kurang mampu mencerminkan hasil kinerja yang sesungguhnya terhadap karyawan dalam waktu satu tahun penilaian.

\section{LANDASAN TEORI}

\section{Manajemen Sumber Daya Manusia}

Menurut Mathis \& Jackson (2012:5) dan Hasibuan (2012:23), manajemen sumber daya manusia (MSDM) dapat diartikan sebagai ilmu dan seni yang mengatur hubungan dan peranan tenaga kerja agar efektif dan efisien dalam penggunaan kemampuan manusia agar dapat mencapai tujuan di setiap perusahaan. Sumber Daya Manusia (SDM) dapat juga disebut sebagai personil, tenaga kerja, pekerja, karyawan, potensi manusiawi sebagai penggerak organisasi dalam mewujudkan eksistensinya, atau potensi yang merupakan aset dan berfungsi sebagai modal non material dalam organisasi bisnis, yang dapat diwujudkan menjadi potensi nyata secara fisik dan non fisik dalam mewujudkan eksistensi organisasi, (Nawawi, 2012).

\section{Penilaian Kinerja Karyawan}

Penilaian kinerja juga bisa didefenisikan sebagai evaluasi sistematis dari kinerja seorang karyawan berdasarkan beberapa aspek pertimbangan dan untuk memahami potensi dari seseorang untuk pertumbuhan lebih lanjut dan pengembangan dari seorang karyawan di suat organisasi dengan peringkat tertentu (Anbarasu, Jenitha, Yulit : 2015). Suatu penilaian kinerja yang baik harus membantu setiap karyawan untuk mengerti akan perannya, mengenali peluang untuk dapat mengambil resiko, mengerti kekuatan dan kelemahan diri sendiri di dalam menjalankan berbagai fungsi perannya tersebut (Veithzal Rivai 2013). Penilaian kinerja karyawan memiliki berbagai manfaat dan tujuan yang dapat dilihat dari beragam persfektif pengembangan pada perusahaan maupun organisasi, khususnya manajemen sumberdaya manusia. Kegiatan Penilaian kinerjamerupakan bagian dari sistem manajemen kinerja dan proses evaluasi terhadap karyawan dalam melakukan pekerjaan yang dikomparasikan dengan standar yang dilanjutkan dengan memberi informasi tersebut pada karyawan. Penilaian kinerja sering disebut juga pemberian peringkat pada karyawan melalui peninjauan, evaluasi, dan penilaian hasil kerja (Mathis dan Jackson, 2006). Sistem penilaian kinerja yang efektif harus dapat memenuhi dua tujuan, yaitu tujuan evaluasi membiarkan orang lain mengetahui posisinya, dan tujuan pengembangan yang memberikan informasi dan arahan tertentu kepada individu, sehingga 
individu tersebut dapat memperbaiki kinerjanya. Mangku prawira (2007) mengemukakan bahwa manfaat penilaian kinerja karyawan dapat ditinjau dari beragam perspektif pengembangan perusahaan, khususnya manajemen SDM, yaitu sebagai berikut: perbaikan kinerja, penyesuaian kompensasi, keputusan penempatan, kebutuhan pelatihan dan pengembangan, perencanaan dan pengembangan karir, defisiensi penetapan staff, ketidakakuratan informasi, kesalahan rancangan pekerjaan, kesmpatan kerja yang sama, tantangan-tantangan eksternal, dan umpan balik.

\section{Motivasi}

Hasibuan (2005) mengungkapkan bahwa motivasi mempersoalkan bagaimana caranya mengarahkan daya dan potensi agar mau bekerja sama secara produktif berhasil mencapai dan mewujudkan tujuan yang telah ditentukan, mau bekerja dan antusias mencapai hasil yang optimal. Menurut Arep dan Tanjung (2012), manfaat motivasi yang utama adalah terciptanya gairah kerja, sehingga produktivitas kerja meningkat, sementara itu, manfaat yang diperoleh karena bekerja dengan orang-orang yang termotivasi adalah: (1) Pekerjaan dapat terselesaikan dengan tepat, dalam arti pekerjaan diselesaikan sesuai stadar dan dalam skala waktu yang sudah ditentukan; (2) Orang akan senang melakukan pekerjaannya; (3) Orang akan merasa dihargai dan diakui keberadaannya; (4) Orang akan bekerja keras dengan adanya dorongan yang tinggi untuk mencapai target yang telah ditetapkan; (5) Tidak membutuhkan terlalu banyak pengawasan; dan (6) Semangat juangnya tinggi dan dapat memberikan suasana bekerja yang bagus di semua bagian.

\section{Produktivitas karyawan}

Produktivitas merupakan hubungan antara segala sesuatu yang digunakan dalam proses produksi suatu barang atau jasa dengan segala keluarannya. Produktivitas pada dasarnya merupakan sikap mental yang selalu berpandangan bahwa mutu hari ini harus lebih baik dari dari hari kemarin dan hari esok lebih baik dari hari ini. Terdapat lima hal yang berhubungan langsung dengan peningkatan produktivitas karyawan, yaitu: (1) Seleksi karyawan, Pengendalian tenaga kerja, Penyempurnaan struktur organisas, Pengembangan sumberdaya manusia dan Motivasi produktivitas yang meliputi perilaku karyawan dalam menyelesaikan tugasnya, mencari metode kerja yang terbaik, kapasitas pelaksanaan tugas yang diberikan oleh pimpinan, kesediaan menyelesaikan tugas pokok orang lain dan melaporkan hasil kerja kepada pimpinan.

Berdasarkan hal tersebut dapat dikatakan bahwa perilaku produktif diartikan sebagai penilaian produktif berdasarkan pada disiplin kerja, seperti mematuhi norma/aturan yang berlaku di organisasi. Perilaku produktif berdasarkan semangat dan gairah kerja yang ditunjukkan oleh karyawan dengan menekan faktor-faktor yang menghambat aktivitas kerja, dan perilaku produktif berdasarkan kepada kebersamaan atau keeratan yang ditunjukkan oleh karyawan dengan bentuk kerjasama dalam unit kerja.

Berdasarkan rumusan masalah, tujuan penelitian serta landasan teori, maka dapat dikemukakan hipotesis sebagai berikut:

1. Materi penilaian berpengaruh signifikan terhadap motivasi karyawan Hotel Pangrango 2 Bogor.

2. Tempat penilaian berpengaruh signifikan terhadap motivasi karyawan Hotel Pangrango 2 Bogor.

3. Metode penilaian berpengaruh signifikan terhadap motivasi karyawan Hotel Pangrango 2 Bogor.

4. Motivasi karyawan berpengaruh signifikan terhadap produktivitas kerja karyawan Hotel Pangrango 2 Bogor. 


\section{METODE PENELITIAN}

Jenis penelitian yang digunakan dalam penelitian ini adalah pendekatan kuantitatif atau analisis data statistik. Data diperoleh dari penyebaran kuesioner tertutup dengan skala likert yang didistribusikan kepada 133 karyawan sebagai sampel penelitian, kemudian data juga diperoleh dari literatur, buku, jurnal dan tesis, serta data dari internet yang dianggap relevan.

\section{HASIL DAN PEMBAHASAN}

Tujuan penelitian untuk menganalisis pengaruh penilaian kinerja terhadap motivasi dan produktivitas kerja karyawan pada hotel pangrango 2 Bogor. Persepsi responden terhadap penilaian kinerja.

Tabel 1

Pendapat Seluruh Responden Mengenai Penilaian Kinerja di Hotel Pangrango 2 Bogor

Frekuensi dan skor jawaban tiap skala

\begin{tabular}{llllllll} 
N0 & Kriteria & 1 & 2 & 3 & 4 & 5 & Skor \\
\hline
\end{tabular}

1. 1. Materi yang berkaitan $\begin{array}{lllllll}\text { dengan tujuan penilaian } & 2 & 3 & 25 & 70 & 34 & 531\end{array}$ (X1)

2. Dimensi waktu secara $\quad \begin{array}{llllll}1 & 5 & 24 & 70 & 33 & 528\end{array}$
periodic pelaksanaan penilaiankinerja

3. Penilaian kinerja secara $\quad \begin{array}{llllll}3 & 6 & 19 & 75 & 30 & 522\end{array}$ informal

4. Potensi/rekomendasi(X4) $\quad \begin{array}{llllll}15 & 29 & 31 & 45 & 13 & 411\end{array}$

2. 1. Lingkungan penilaian dilakukan dalam suasana nyaman (X5)

$\begin{array}{llllll}4 & 7 & 23 & 61 & 38 & 521\end{array}$

2. Pelaksanaan penilaian dilakukan di luar kantor (X6)

$\begin{array}{llllll}23 & 44 & 40 & 19 & 7 & 342\end{array}$

3. 1. Deskipsi tugas dan tanggung jawab(X7)

2. Metode penilaian telah memenuhi harapan(X8)

$\begin{array}{llllll}6 & 9 & 30 & 52 & 36 & 502\end{array}$

\section{Analisis pengaruh peubah laten eksogen (penilaian kinerja) terhadap peubah laten endogen (motivasi kerja)}

\section{Materi/isi penilaian}

Materi penilaian kinerja yang diteliti meliputi dimensi waktu periodik, penilaian kinerja secara informal, dan potensi/rekomendasi dari seorang karyawan. Berdasarkan jawaban responden secara keseluruhan berada pada rentang setuju. Pendapat responden mengenai kurun waktu penilaian yang dilakukan tiap tahun sekali berada pada rentang setuju. Demikian juga dengan penilaian secara informal yang dilakukan oleh atasan terhadap karyawan juga pada rentang setuju. Sementara rekomendasi penilai terhadap potensi seorang karyawan maupun kekurangannya menurut para responden berada pada 
rentang tidaksetuju. Berdasarkan analisis bahwa terdapat pengaruh positif antara variabel laten materi penilaian terhadap variabel laten terikat motivasi yaitu $36.50>1.96$ dengan koefisien lintas 1.03 adalah signifikan. Dengan demikian, materi penilaian yang digunakan Hotel Pangrango 2 Bogor untuk menilai kinerja karyawan sudah sesuai.

a. Tempat pelaksanaan penilaian

Pendapat responden mengenai tempat pelaksanaan penilaian secara umum berada pada rentang setuju, terutama bila dilakukan dalam lingkungan yang nyaman didalam kantor tempat masing-masing karyawan bekerja. Akan tetapi hasil analisis menunjukan tempat pelaksanaan penilaian tidak berpengaruh terhadap motivasi karena nilai-t sebesar $1.76<1.96$ dengan koefisien lintas 0.00 dengan kata lain tidak signifikan.

b. Metode penilaian

Metode penilaian yang digunakan juga pada rentang setuju karena telah cukup memenuhi harapan karyawan dalam menilai kinerjanya sebagai seorang karyawan. Akan tetapi berdasarkan analisis pengaruh variabel laten bebas (metode penilaian) terhadap variabel laten terikat (motivasi) memiliki nilai-t $-8.31<1.96$ dengan koefisien lintas -0.12 signifikan (berpengaruh negatif). Hal ini mengindikasikan bahwa metode yang selama ini diterapkan belum memenuhi harapan karyawan pada Hotel Pangrango 2 Bogor.

\section{Analisis pengaruh peubah laten endogen motivasi terhadap produktivitas kerja} karyawan dengan indikatorpembentuknya

Pada penelitian ini terdapat 12 peubah indikator laten endogen yang diukur, yaitu penghargaan yang diberikan (Y1), ketepatan menggunakan metode (Y2), tanggung jawab terhadap pekerjaan (Y3), imbalan dalam bentuk materi (Y4), hubungan sesama pegawai (Y5), kondisi ruangan kerja (Y6), memotivasi dan membangun kerja sama (Y7), jujur dalam melaporkan hasil (Y8), mengutamakan kepentingan tugas (Y9), mentaati peraturan kerja (Y10), mentaati ketentuan jam kerja (Y11), dan mentaati perintah atasan (Y12).

\section{Tabel 2}

Kontribusi Peubah Motivasi dan Produktivitas Kerja Karyawan.

\begin{tabular}{|c|c|c|c|c|}
\hline $\begin{array}{l}\text { Faktor } \\
\text { Muatan }\end{array}$ & & Atribut & $\begin{array}{l}\text { Faktor } \\
\text { Muatan }\end{array}$ & $\begin{array}{c}\mathrm{t}- \\
\text { value }\end{array}$ \\
\hline \multirow{12}{*}{1.00} & \multirow{5}{*}{ 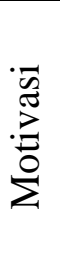 } & Y1. Penghargaan yang diberikan & 0.33 & 0.00 \\
\hline & & Y2. Ketepatan menggunakan metode & 0.11 & 0.8 \\
\hline & & Y3. Tanggung jawab terhadap pekerjaan & 0.33 & 3.0 \\
\hline & & Y4. Imbalan dalam bentuk materi & -0.03 & -0.21 \\
\hline & & Y5. Hubungan sesama pegawai & 0.34 & 2.6 \\
\hline & \multirow{7}{*}{ 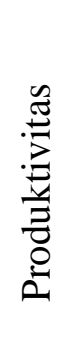 } & Y6. Kondisi ruangan kerja & -0.09 & -0.70 \\
\hline & & Y7. Memotivasi dan membangun kerja sama & 0.55 & 0.00 \\
\hline & & Y8. Jujur dalam melaporkan hasil & 0.16 & 1.6 \\
\hline & & Y9. Mengutamakan kepentingan tugas & 0.10 & 1.0 \\
\hline & & Y10. Mentaati peraturan kerja & 0.43 & 4.3 \\
\hline & & Y11. Mentaati ketentuan jam kerja & 0.48 & 5.5 \\
\hline & & Y12. Mentaati perintah atasan & 0.40 & 4.1 \\
\hline
\end{tabular}


Berdasarkan hasil estimasi yang telah dilakukan, dan didapat nilai faktor muatan dan nilai-t dari setiap indikator konstruk motivasi memiliki $6.74>1.96$ dengan koefisien lintas 1.00 yang berarti signifikan (berpengaruh positif). Selanjutnya hasil penelitian juga memperlihatkan bahwa peubah indikator penghargaan yang diberikan (Y1) sebagai pembanding memberikan nilai faktor muatan sebesar 0.33 . Kondisi ini menggambarkan bahwa pemberian penghargaan yang selama ini diterapkan oleh pihak manajemen Hotel Pangrango 2 Bogor belum sesuai atau tidak sesuai dengan harapan para karyawan, dengan demikian perlu dicarikan format atau model yang sesuai untuk memberikan penghargaan kepada karyawan, baik itu berbentuk fisik maupun psikis.

Dari Tabel 2, dapat dilihat bahwa peubah indikator imbalan dalam bentuk materi (Y4) memberikan kontribusi sebesar -0.03 atau lebih lebih tinggi dari peubah indikator dari peubah indikator penghargaan yang diberikan (Y1) sebagai pembanding. Hal ini menunjukkan karyawan di Hotel Pangrango 2 Bogor menganggap bahwa gaji merupakan faktor yang paling dominan dalam pembentukan laten endogen hygienis. Imbalan dalam bentuk materi (gaji) merupakan salah satu unsur yang penting agar dapat meningkatkan motivasi dan produktivitas kerja karyawan, sebab gaji adalah alat untuk memenuhi berbagai kebutuhan pegawai (Hariandja 2007). Selanjutnya Peubah indikator hubungan sesama dengan pegawai (Y5) memberikan kontribusi sebesar 0.34.Sejauh ini, karyawan Hotel Pangrango 2 Bogor selalu berorientasi pada penyelesaian tugas sehingga waktu untuk berinteraksi dengan sesama karyawan di luar tugas resmi tidak banyak.Berikutnya Peubah indikator ruangan kerja (Y6) memberikan kontribusi sebesar -0.09 kali lebih rendah dari peubah indikator imbalan dalam bentuk materi (Y4).Jika dilihat secara keseluruhan, peubah indikator kondisi ruangan kerja (Y6) memberi kontribusi yang sangat rendah dibanding peubah-peubah indikator lainnya. Hal ini menunjukkan bahwa karyawan Hotel Pangrango 2 Bogor merasa tidak ada kepuasan kerja dengan kondisi ruangan tempat mereka bekerja. Kondisi ruangan yang baik seperti ruangan bersih, teratur, rapi, sejuk, sirkulasi udara lancar, cukup luas dan tidak menghambat gerakan dalam bekerja dapat menimbulkan motivasi kerja yang positif.

\section{Implikasi Manajerial}

Berdasarkan hasil penelitian yang telah dibahas, maka implikasi manajerial yang dapat disampaikan adalah sebagai berikut:

1. Dilihat dari kontribusinya terhadap motivasi dan produktivitas kerja karyawan, peubah laten eksogen materi penilaian memiliki kontribusi sebesar 1.03. Hal ini berarti materi penilaian memiliki kontribusi terbesar dalam membangun motivasi dan produktivitas kerja karyawan Hotel Pangrango 2 Bogor.

2. Dilihat dari kontribusinya terhadap motivasi dan produktivitas kerja karyawan, peubah laten metode penilaian kinerja karyawan mempunyai nilai faktor muatan sebesar -0.12. Hal ini menjelaskan bahwa metode yang digunakan selama ini dalam menilai kinerja karyawan dapat dikatakan belum memenuhi harapan karyawan.

\section{SIMPULAN}

Berdasarkan hasil analisis dari studi kasus pada Hotel Pangrango 2 Bogor, dapat diambil kesimpulan sebagai berikut:

1. Penilaian kinerja (Performance Appraisal) yang dilakukan manajemen Hotel Pangrango 2 Bogor kepada para karyawannya selama ini adalah penilaian diri sendiri (Self Appraisal).

2. Pengaruh variabel laten materi penilaian terhadap variabel laten motivasi dalam menilai kinerja karyawan sudah efektif.

3. Variabel laten (tempat penilaian) terhadap variabel laten terikat (motivasi) tidak berpengaruh. 
4. Variabel latenbebas (metode penilaian)terhadapvariabelterikat(motivasi)memiliki pengaruh negative.

5. Movitasi berpengaruh positif terhadap produktivitas kerja karyawan Hotel Pangrango 2 Bogor

Adapun saran dari hasil penelitian ini adalah sebagai berikut :

1. Bagi Penulis

Responden yang digunakan dalam penelitian ini hanya terbatas pada suatu lingkungan kerja hotel pangrango 2 sehingga pada penelitian selanjutnya dapat diikutsertakan contoh yang lebih luas misalnya pada perusahaan lain dalam industri sejenis,menggunakan variabel-variabel penilaian kinerja lainnyayang dapat memotivasi kerja karyawan, melakukan pengembangan model mengenai penilaian kinerja, pengolahan data dengan membandingkan antara karyawan laki-laki dan perempuan. Sehingga hasil penelitian dapat digeneralisasikan dan menghasilkan informasi-informasi yang lebih jelas dalam pengelolaan sumberdaya manusia sebuahorganisasi.Secara akademik, hasil penelitian tentang pengaruh penilaian kinerja terhadap motivasi dan produktivitas kerja karyawan pada hotel pangrango 2 Bogor bisa dijadikan sebagai wawasan tambahan terhadap ilmu pengetahuan di bidang manajemen khususnya manajemen perhotelan untuk dapat dijadikan kajian bagi peneliti lain. Selain itu, hasil penelitian ini bisa juga menjadi acuan bagi yang sedang berkerja ataupun ingin berkerja pada bidang perhotelan.

2. Bagi Hotel Pangrango 2 Bogor

Hasil penelitian menunjukan bahwa penilaian kerja karyawan sangat penting dilakukan dan motivasi berpengaruh terhadap produktivitas kerja karyawan. Sehingga pihak hotel perlu memperhatikan hal-hal yang dapat membangkitkan movitasi kerja karyawan dan prosedur penilaian tehadap kinerja karyawan haruslah dalam kerangka Manajemen Kinerja (Performance Management) yang terintegrasi.Hotel hendaknya melakukan analisis jabatan dengan lebih baik dan mendalam sehingga penilaian kinerja dapat disesuaikan dengan jabatan-jabatan yang ada dan pada akhirnya dapat menilai seluruh jabatan dengan baik. Dan juga hotel hendaknya membuat pedoman pembuatan buku catatan penilaian yang lengkap sehingga dapat memberikan gambarankinerja karyawan yang sebenarnya.

\section{DAFTAR PUSTAKA}

Anbarasu, V., Jenitha, A. and Yulit, J.J.. (2015). Employee Performance Appraisal System Using Fuzzy Logic. International Journal Of Innovative Research\& Development, 4(3), pp.232-238.

Arep.I dan tanjung, H. (2012). Manajemen Sumberdaya Manusia. Universitas Trisakti. Jakarta

Hariandja, M.T.E. (2007). Sumber Daya Manusia : Pangadaan, Pengembangan, Pengkompensasian, dan Peningkatan Produktivitas Pegawai. Jakarta. PT Gramedia Widiasarana Indonesia.

Hasibuan, Malayu. (2005). Manajemen Sumber Daya Manusia. Edisi Revisi. Jakarta : PT. Bumi Aksara

Hasibuan, Malayu. (2012). “Manajemen Sumber Daya Manusia”. Jakarta : PT. Bumi Aksara

Mangkunegara, A.P. (2013). Manajemen Sumber Daya manusia Perusahaan. Bandung. Cetakan Ketiga. PT Remaja Rosdakarya.

Mathis, R.L. \& J.H. Jackson. (2006). Human Resource Management: Manajemen Sumber Daya Manusia. Terjemahan Dian Angelia. Jakarta: Salemba Empat 
Mathis, Robert L. dan John H. Jackson. (2012). Manajemen Sumber Daya Manusia Edisi Pertama. Jakarta: Salemba Empat.

Mangkupawira dan Vitayala. (2007). Manajemen Mutu SDM. Bogor : Ghalia Indonesia.

Nawawi, Hadari. (2012). Metode Penelitian Bidang Sosial. Yogyakarta: Gajah Mada University Press.

Rohmanowati. (2005). Tesis Hubungan Kepuasan Kerja Terhadap Motivasi Kerja dan Efektivitas Kepemimpinan di Pusdiklat Pegawai Departemen Pendidikan Nasional Sawangan. Program studi Magister Manajemen. IPB

Veithzal Rivai, (2013). Manajemen Sumber Daya Manusia Untuk Perusahaan Dari Teori Ke Praktek. Bandung: Raja Grafindo Persada. 